\title{
Effects of soaking and grinding conditions on anti-nutrient and nutrient contents of soy milk
}

\author{
Humyra Nowshin, Kumkum Devnath, Anjuman Ara Begum and Md. Anisur Rahman Mazumder
}

Department of Food Technology and Rural Industries, Faculty of Agricultural Engineering and Technology, Bangladesh Agricultural University, Mymensingh- 2202, Bangladesh

\begin{tabular}{|c|c|}
\hline ARTICLE INFO & Abstract \\
\hline $\begin{array}{l}\text { Article history: } \\
\text { Received: } 25 \text { February } 2018 \\
\text { Accepted: } 08 \text { April } 2018\end{array}$ & $\begin{array}{l}\text { Although soy milk is a very good source of nutrient with high biological value, the presence of anti- } \\
\text { nutritional factors affects its nutrition quality and limits bioavailability of the nutrients. The effects of } \\
\text { soaking duration and combination of soaking and grinding (hot or cold) on phytate, lipoxygenase, urease, } \\
\text { trypsin inhibitor activity, protein solubility and other nutrient contents were investigated. Soaking alone at }\end{array}$ \\
\hline $\begin{array}{l}\text { Keywords: } \\
\text { Soy milk, soaking, grinding, } \\
\text { phytate, protein solubility }\end{array}$ & $\begin{array}{l}55 \text { and } 60^{\circ} \mathrm{C} \text { for different durations was found effective for the reduction of lipoxygense activity. } \\
\text { Combination of soaking, blanching }\left(80^{\circ} \mathrm{C} \text { for } 10 \text { min) and hot grinding }\left(100^{\circ} \mathrm{C}\right) \text { significantly }(\mathrm{P}>0.05)\right. \\
\text { reduced urease activity, more than } 80 \% \text { phytate activity and deactivated trypsin inhibitor, but did not } \\
\text { affect protein solubility. Meanwhile, protein solubility }(10-15 \%) \text { was increased due to hot grinding. Soy } \\
\text { milk extracted from soaking at } 55 \text { and } 60^{\circ} \mathrm{C} \text { for } 2,4 \text { and } 6 \text { h with hot grinding provided higher protein }\end{array}$ \\
\hline $\begin{array}{l}\text { Correspondence: } \\
\text { Md. Anisur Rahman Mazumder } \\
\text { (anis_engg@bau.edu.bd) }\end{array}$ & $\begin{array}{l}\text { content compared to cold grinding. Increase in soaking temperature from } 55 \text { to } 60^{\circ} \mathrm{C} \text { increased the } \\
\text { extracted solid content having a potential fraction of lipid. Increasing soaking time from } 4 \text { to } 6 \mathrm{~h} \text { did not } \\
\text { show any significant difference in terms of phytate inhibition, urease activity reduction, trypsin inhibition } \\
\text { and protein solubility except lipoxygenase activity. The results suggested that soaking of soybean at } 60^{\circ} \mathrm{C} \\
\text { for } 6 \mathrm{~h} \text { and hot grinding }\left(100^{\circ} \mathrm{C}\right) \text { with blanching at } 80^{\circ} \mathrm{C} \text { for } 10 \text { min is the best for reducing anti-nutrient } \\
\text { and retaining nutrient activity for soy milk and other soy-based products. }\end{array}$ \\
\hline
\end{tabular}

\section{Introduction}

Soybean foods have become increasingly popular since the US Food and Drug Administration (FDA) approved a health claim for the cholesterol-lowering effects of soy protein. Their claimed largely based on a meta-analysis of 38 clinical trials that reported significant decreased in total and low-density lipoprotein (LDL) cholesterol and triglycerides with soy protein intake (25 g/day) compared with animal protein consumption (Adlercreutz et al., 1995). Researches revealed that soy products could prevent heart disease, obesity, blood cholesterol, cancer, diabetes, kidney disease, osteoporosis and blood pressure (Garcia et al., 1997; Hassler, 1998; Liu, 1997; Riaz, 1999). Soy milk is a water extract of soybean, a grain legume and one of the oldest known food sources of the world of human beings. It is typically produced by grinding soaked soybeans with water. It is an inexpensive and convenient source of high quality protein. Soy milk is one of the most important traditional beverages that are consumed widely in Asian countries, including China, Japan, Korea, Singapore and Thailand. In recent decades, extensive evidence has indicated the strong relationship between soy food consumption and health-promoting effects. Soy milk provides a balanced nutrient combination, which is similar to cow's milk, but free of cholesterol, gluten and lactose plus favorable phytochemical compounds linked to health. Among vegetarians, milk allergy patients or people with lactose intolerance, soy milk could be used as a daily alternative. As soy milk contained high amounts of protein, poly-unsaturated fatty acids, vitamins, minerals and phytochemicals, it could be easily used as a good source of nutrition food for malnourished people, especially in developing countries (Mazumder and Begum, 2016). In response to a gradual increase in sales and consumption, various new products have been introduced into the soy market. Some basic changes are made to the flavor and soybean source. However, the most recent innovations are focused on producing "functional soy milk". Functional soy milk can be considered as soy milk that contains extra bioactive components and may help to enhance health or lower risk of diseases. Soybean is a good source of phenolic compounds with antioxidant properties and has an extraordinarily high amount of isoflavones, a group of phytoestrogens that have been reported to possibly lower the risk of hormonal and age-related diseases. Among isoflavones, genistein being a powerful inhibitor of tyrosine carries additional small molecular modifiers, such as kinase activity in vitro (Akiyama et al., 1987). More importantly, genistein could act as an anti-oxidant and anti-browning agents in in vivo and in vitro (Mazumder and Hongsprabhas, 2016a). However, the presence of natural anti-nutrients, such as trypsin inhibitors (TI), lectins, phytic acids, and indigestible oligosaccharides, has limited the consumption of soybean and its products.

The presence of protease inhibitors, Kunitztrupsin inhibitor (KTI) and Browman-Birk inhibitor of 
chymotrypsin (BBI) results in the reduction of protein digestibility and thus limits the availability of essential amino acids such as trypsin (Dia et al., 2012; Monteiro et al., 2004). Phytic acid might reduce the bioavailability of proteins by binding to peptides and amino acids and thereby inhibits proteolytic enzyme action (Deak and Johnson, 2007). Moreover, lipoxygenases lead to the socalled beany flavor by catalyzing lipid hydroperoxidation and thus limit the consumption of soy products (Esteves et al., 2010; Felix et al., 2011). So, modifying the processing methods could be an effective way to improve the health-promoting bioactive components and/or reduce the undesired compounds originally present in soybeans in order to support functional soy milk product development. The soaking and heating process during soy milk extraction considerably destroys most of the anti-nutritional factors present in soybean and improves the digestibility of soy protein (Mazumder, 2016). This research aimed to evaluate the effects of soaking time-temperature and hot grinding on the anti-nutritional factors such as phytate, lipoxygenase, urease activity, protease and trypsin inhibitor, protein solubility and other nutrient content of soy milk.

\section{Materials and Methods}

\section{Soy milk extraction}

Soy milk was extracted by the modified method described by Mazumder (2016). Prior to grinding, the soybeans were soaked in $0.5 \%$ sodium bicarbonate solution at 55 and $60^{\circ} \mathrm{C}$ for 2,4 and $6 \mathrm{~h}$ in a water bath (JSSB-30T, Korea). The ratio of soybean and water for soaking was 1:2. The beans were drained well after wards. After discarding water, the soaked soybean was dehulled manually with hands to remove unwanted substances before grinding. Hydrated beans were blanched in $0.5 \%$ sodium bicarbonate solution at $80^{\circ} \mathrm{C}$ for $10 \mathrm{~min}$. The solution was then drained well and washed with potable water for three times. The blanched soybean was grinded with addition of hot water $\left(100^{\circ} \mathrm{C}\right)$ or cold water by using super mass colloider and a basket centrifuge. The ratio of soybean to water was 1:4. Soy milk was obtained after filtering through double layers of cheese cloths. The soy milk was stored at $-18^{\circ} \mathrm{C}$ for further studies. Soy milk prepared by different methods was analyzed for total solid, protein, fat, protein solubility, phytae, lipoxygenase, urease activity and tripsin inhibitor. Moisture content for total solid, protein and fat content was determined following AOAC (1999).

\section{Determination of lipooxygenase (LOX) assays of soy milk}

One hundred milliliter $(100 \mathrm{ml})$ of soy milk was centrifuged at $25,000 \times \mathrm{g}$ for $20 \mathrm{~min}$ at room temperature. The supernatant was used for the crude enzyme extract. LOX activity was measured as the change in absorbance at $234 \mathrm{~nm}$ with a linolenic acid substrate solution according to Gokmen et al. (2002). A double beam spectrophotometer (Photolab 7600UVVIS) and $1 \mathrm{~cm}$ path-length cuvette were used for enzyme measurement.

\section{Determination of phytate activity of soy milk}

Extraction of phytate was done for $1 \mathrm{~h}$ in a $20 \mathrm{ml}$ vial with $0.5 \mathrm{~N} \mathrm{HCl}$ in a ratio of $1: 20(\mathrm{w} / \mathrm{v})$ while stirring. 0.5 $\mathrm{ml}$ of soy milk and $10 \mathrm{ml}$ of $0.5 \mathrm{~N} \mathrm{HCl}$ was used throughout. Approximately $2 \mathrm{ml}$ of crude extract of each sample was centrifuged at $18,000 \times \mathrm{g}$ for $10 \mathrm{~min}$ in a micro-centrifuge. An aliquot of $1 \mathrm{ml}$ of supernatant containing phytate was then filtered with a $1 \mathrm{ml}$ tuberculin syringe and a $13-\mathrm{mm} / 0.45-\mu \mathrm{m}$ syringe filter. Filtered samples could be stored at $4^{\circ} \mathrm{C}$ for several days prior to HPLC analysis.

Phytate was determined by the modified method as described by Rounds and Nielsen (1993). Elution of phytate for HPLC analysis was achieved by using a 30min linear gradient of $0.01 \mathrm{M}$ 1-methylpiperazine at $\mathrm{pH}$ 4.0 and $0.5 \mathrm{M} \mathrm{NaNO}_{3}$ in $0.01 \mathrm{M}$ 1-methylpiperazine at $\mathrm{pH} 4.0$ with a flow rate of $1 \mathrm{ml} / \mathrm{min}$. Wade's color reagent consisting of $0.015 \%(\mathrm{w} / \mathrm{v}) \mathrm{FeCl}_{3}$ and $0.15 \%$ (w/v) 5-sulfosalicylic acid was prepared based on Wade and Morgan (1955) having a flow rate of $1 \mathrm{ml} / \mathrm{min}$. Phytate eluted from the column were mixed with Wade's reagents in a mixing tee with inline check valves for both eluents installed prior to the mixing tee to prevent backflow. The post column reaction was allowed to take place in $0.05 \times 210 \mathrm{~cm}$ poly ether ketone tubing at a combined flow rate of $2 \mathrm{ml} / \mathrm{min}$. The absorbance was monitored at $500 \mathrm{~nm}$ and the detector signals and/or phytate peaks were processed and integrated by chromatographic data acquisition system.

\section{Determination of urease activity of soy milk}

The urease activity was determined by an assay method described by Croston et al. (1955). The $\mathrm{pH}$ of the urease-urea reaction should maintain 6.8 to prevent a decrease in urease activity with increasing alkalinity. All reactions were carried out in a constant temperature bath at $40^{\circ} \mathrm{C}$. The reagents used were $0.1 \mathrm{~N} \mathrm{HCl}, 0.1 \mathrm{~N}$ $\mathrm{NaOH}$, phosphate buffer of $\mathrm{pH} 6.8$ made up of 0.025 mole of $\mathrm{K}_{2} \mathrm{HPO}_{4}, 0.025$ mole $\mathrm{KH}_{2} \mathrm{PO}_{4}$ and $0.8 \mathrm{~g}$ of glutathione per liter and the buffered urea solution was prepared daily by dissolving $6 \mathrm{~g}$ urea in $100 \mathrm{ml}$ of buffer solution without the glutathione.

Twenty milliliter (20 ml) of soy milk was added to $5 \mathrm{ml}$ of the buffer solution containing glutathione, and was allowed to stand for $30 \mathrm{~min}$ at $40^{\circ} \mathrm{C}$. Five milliliter (5 $\mathrm{ml}$ ) of the buffered urea solution was then added to initiate the reaction. The $\mathrm{pH}$ of the reaction was maintained at approximately 6.8 by slowly adding $0.1 \mathrm{~N}$ $\mathrm{HCl}$ and using bromthymol blue in its green color range toindicate the desired end-point. At the end of $30 \mathrm{~min}$, the reaction was terminated by rapidly adding additional $0.1 \mathrm{~N} \mathrm{HCl}$ to a total of $10 \mathrm{ml}$ or more. The system was then titrated with $0.1 \mathrm{~N} \mathrm{NaOH}$ to $\mathrm{pH} 4.7$. A control was 
run parallel with each sample. For the control, the urease was inactivated by adding $\mathrm{HCl}$ to the sample before adding phosphate buffer and buffered urea solution. The difference between the control and sample in ml of $0.1 \mathrm{~N}$ $\mathrm{HCl}$ or its ammonia equivalent was taken as the urease activity of the meal.

\section{Determination of trypsin inhibitor in soy milk}

Trypsin inhibitor activity was determined according to the modified method described by Erlanger et al. (1961). Fifty milligram $(50 \mathrm{ml})$ of soy milk and $5 \mathrm{ml}$ of $0.1 \mathrm{M}$ Tris-HCl buffer were mixed together to adjust $\mathrm{pH}$ 8.2. The solution was homogenized in an Erlenmeyer containing $20 \mathrm{mM} \mathrm{CaCl}_{2}$ and agitated for $3 \mathrm{~h}$ followed by centrifugation for $3600 \times \mathrm{g}$ for $20 \mathrm{~min}$. One hundred milliliter $(100 \mathrm{ml})$ of soy milk was added with $450 \mu \mathrm{l}$ of buffer and $50 \mu \mathrm{l}$ of trypsin solution in a test tube and homogenized followed by keeping the suspension at room temperature for 10 minutes. $500 \mu$ l of the homogenate was transferred to a new test tube containing $500 \mu \mathrm{l}$ of buffer and $500 \mu \mathrm{l}$ of D, L-BApNA solution. The solution was agitated for few minutes and left at room temperature for 10 minutes; the reaction was stopped by adding $300 \mu \mathrm{l}$ of $60 \%$ acetic acid. Absorbance of the solution was determined at $410 \mathrm{~nm}$ using a spectrophotometer (Photolab 7600UV-VIS) and the results were converted in milligram of inhibited trypsin per gram of total protein in the sample.

\section{Determination of protein solubility of soy milk}

Protein solubility of soy milk was determined based on nitrogen (N) solubility (Mazumder, 2016). Fifty milliliter $(50 \mathrm{ml})$ soy milk was centrifuged at $10,000 \mathrm{x} \mathrm{g}$ for $10 \mathrm{~min}$ at room temperature to separate solid and liquid. The suspension was pipetted and $\mathrm{N}$ solubility was determined by using Lowry method (Lowry et al., 1952). Protein solution $(0.3 \mathrm{ml})$ was added in test tubes with $0.3 \mathrm{ml} 2 \mathrm{M} \mathrm{NaOH}$. The solution was heated at $100^{\circ} \mathrm{C}$ for $10 \mathrm{~min}$ and cooled at room temperature $\left(25^{\circ} \mathrm{C}\right)$. Three milliliter $(3 \mathrm{ml})$ of complex forming agent (2\% sodium carbonate, $1 \%$ copper sulphate and $2 \%$ sodium potassium tartarate) was added to the solution. The solution was then mixed well. This solution was incubated at room temperature for $10 \mathrm{~min}$. Then $0.3 \mathrm{ml}$ of Folin-Ciocalteau solution (reagent solution) was added to each tube and incubated for $30 \mathrm{~min}$ (not more than $60 \mathrm{~min})$. Absorbance of the solution was determined at $550 \mathrm{~nm}$ using a spectrophotometer (Photolab 7600UV-VIS). The absorbance was plotted against protein concentration to get a standard calibration curve and calculate percent nitrogen solubility.

\section{Results and Discussion}

Effect of combination of soaking, blanching and hot grinding on lipoxygeanse (LOX) content of soy milk

Figure 1 illustrates the residual enzyme activities during soaking of soybean at different soaking conditions. Soaking at $55^{\circ} \mathrm{C}$ for $6 \mathrm{~h}$ showed around 85\% reduction of LOX activities. Rapid inactivation was observed in soybean $\mathrm{LOX}$ at $60^{\circ} \mathrm{C}$ for different duration. Soaking at $60^{\circ} \mathrm{C}$ for $6 \mathrm{~h}$ was found sufficient to inactivate $100 \%$ of LOX's activity. As 100\% LOX activity reduction was achieved by hot soaking, the effects of cold or hot grinding studies did not continue for LOX activity. The result suggested that soaking at $60^{\circ} \mathrm{C}$ for $6 \mathrm{~h}$ was sufficient to reduce $100 \%$ LOX activity. Bahceci et al. (2005) found that $60^{\circ} \mathrm{C}$ could reduce $90 \%$ LOX activity within the first $10 \mathrm{~min}$, and the residual activity remained relatively stable during further $20 \mathrm{~min}$.

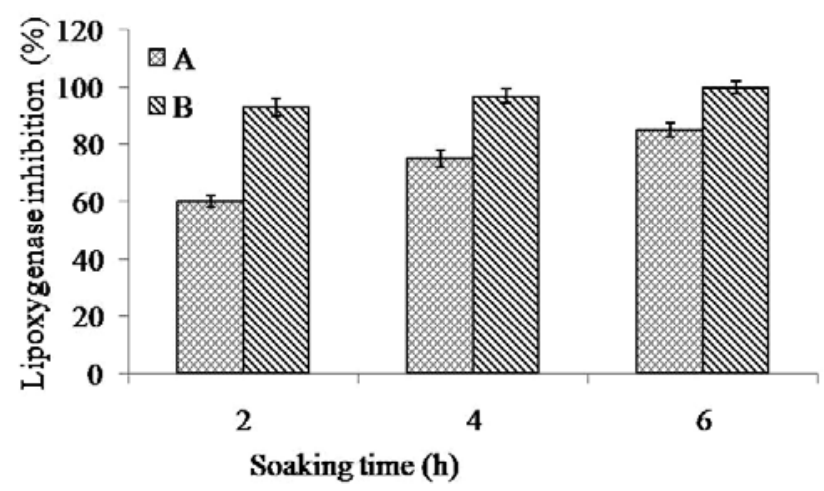

Fig. 1. Effect of soaking temperature and time on lipoxygenase activity in the soy milk. Bars represent standard deviation. $\mathrm{A}=$ Soybean soaking at $55^{\circ} \mathrm{C}$ temperature. $\mathrm{B}=$ Soybean soaking at $60^{\circ} \mathrm{C}$ temperature.

Reduction of $>90 \%$ LOX activity was recommended for optimum quality of vegetable during frozen storage. However, the extraction of soy milk requires $100 \%$ inhibition of LOX activity since soybean contained lot of anti-nutritional factors such as saponins, phospholipids, protease inhibitors, phytates and trypsin inhibitors (Giri and Mangaraj, 2012). Hence, blanching is an obvious pre-treatment during extraction of soy milk.

Effect of combination of soaking, blanching and hot grinding on phytate content of soy milk

Figure 2 illustrates the phytate activities during soaking of soybean at different soaking conditions and at combination of soaking, blanching and hot grinding. Only soaking at $55^{\circ} \mathrm{C}$ for $6 \mathrm{~h}$ showed around $21 \%$ reduction of phyate activity though it is not significantly ( $>>0.5$ ) different with that at $55^{\circ} \mathrm{C}$ for $4 \mathrm{~h}$. Although soaking at $60^{\circ} \mathrm{C}$ for $6 \mathrm{~h}$ showed $27 \%$ reduction of phyate activity, it is statistically similar with that at $60^{\circ} \mathrm{C}$ for 4 h. The result suggested for further heat treatment of soybean before extraction of soy milk. Blanching temperature was set at $80^{\circ} \mathrm{C}$ for 10 min based on Mazumder and Hongsprabhas (2016b) and Mazumder and Begum (2016). Combination of soaking, blanching $\left(80^{\circ} \mathrm{C}\right.$ for $\left.10 \mathrm{~min}\right)$ and cold or hot grinding $\left(100^{\circ} \mathrm{C}\right)$ showed rapid inactivation of soybean phytate. Soaking at 55 and $60^{\circ} \mathrm{C}$ for different time periods showed significant difference in phytate reduction, both in cold and hot grinding. Similarly, cold grinding and hot grinding also showed significant difference in phytate reduction. Maximum amount of phytate was reduced with a combined treatment of soaking $\left(60^{\circ} \mathrm{C}\right.$ for $\left.6 \mathrm{~h}\right)$, blanching $\left(80^{\circ} \mathrm{C}\right.$ for $\left.10 \mathrm{~min}\right)$ and hot grinding $\left(100^{\circ} \mathrm{C}\right)$. 


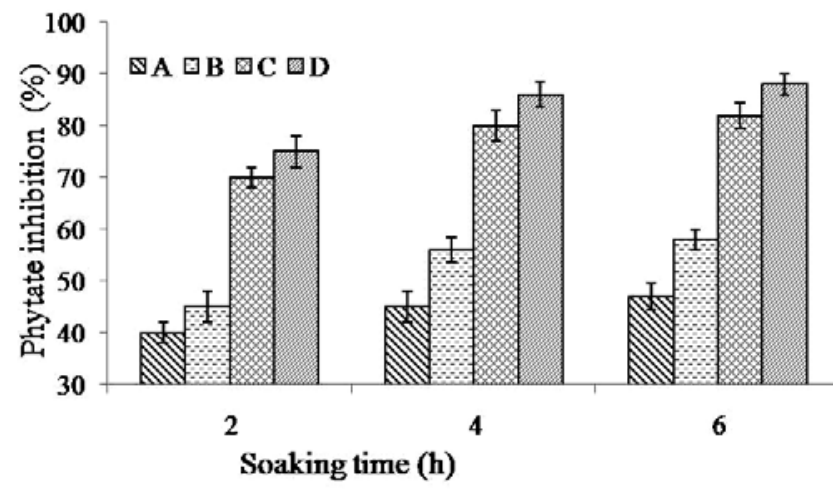

Fig. 2. Combined effect of soaking temperature-time, blanching $\left(80^{\circ} \mathrm{C}\right.$ for $\left.10 \mathrm{~min}\right)$ and grinding conditions on the phytate activity in soy milk. $\mathrm{A}=$ Combination of soaking $\left(55^{\circ} \mathrm{C}\right)$, blanching $\left(80^{\circ} \mathrm{C}\right.$ for $\left.10 \mathrm{~min}\right)$ and cold grinding. $\mathrm{B}=\mathrm{Combination}$ of soaking $\left(60^{\circ} \mathrm{C}\right)$, blanching $\left(80^{\circ} \mathrm{C}\right.$ for $\left.10 \mathrm{~min}\right)$ and cold grinding. $\mathrm{C}=$ Combination of soaking $\left(55^{\circ} \mathrm{C}\right)$, blanching $\left(80^{\circ} \mathrm{C}\right.$ for $\left.10 \mathrm{~min}\right)$ and hot grinding $\left(100^{\circ} \mathrm{C}\right) . \mathrm{D}=$ Combination of soaking $\left(60^{\circ} \mathrm{C}\right)$, blanching $\left(80^{\circ} \mathrm{C}\right.$ for $\left.10 \mathrm{~min}\right)$ and hot grinding $\left(100^{\circ} \mathrm{C}\right)$. Bars represent standard deviation.

Most of the anti-nutrients in the beans and legumes are found in the skin, and many of them are water-soluble; they simply dissolve when soaked in water (Fernandes et al., 2010). In legumes and beans, soaking has been found to reduce phytate, protease inhibitors, lectins, tannins and calcium oxalate. Twelve-hour (12 h) soaking reduced the phytate content of peas by up to $9 \%$ (Bishnoi et al., 1994). However, the reduction of antinutrients might depend on the type of beans. In kidney beans, soybeans and faba beans, soaking reduces protease inhibitors only very slightly (Dhurandhar and Chang, 1990; Liu and Markakis, 1987; Sharma, 1992). Similarly, soaking is useful for leafy vegetables to reduce some of their calcium oxalate (Savage and Dubois, 2006).

It is very essential to reduce phytate in soy milk or soy food because phytate inhibits calcium absorption. It reduces iron, zinc, magnesium and calcium absorption, and resulted in poor iron absorption in soy foods (Mazumder and Hongsprabhas, 2016b; Schlemmer et al., 2009). But, vitamin C could increase the amount of iron absorbed from soy foods, although absorption rates are still low. Iron may be better absorbed from fermented soy foods like tempeh and miso than soy milk (Mazumder and Hogsprabhas, 2016b). Reduction of around $90 \%$ phytate activity will help to absorb calcium content of soy milk. To increase the calcium absorption, calcium-fortified soy milk should be supplied in the markets.

\section{Effect of combination of soaking, blanching and hot grinding on urease activity of soy milk}

The urease activity of the raw soybean was significantly higher $(p<0.05)$ than that of the soybean soaked at 55 and $60^{\circ} \mathrm{C}$ for different time periods. Soaking at $55^{\circ} \mathrm{C}$ for 6 h showed maximum $45 \%$ reduction of urease activity (not significantly different with $55^{\circ} \mathrm{C}$ for $4 \mathrm{~h}, 44 \%$ reduction), while $60 \%$ reduction was observed for soaking at $60^{\circ} \mathrm{C}$ for the same time period (not significantly different with $60^{\circ} \mathrm{C}$ for $4 \mathrm{~h}, 58.5 \%$ reduction, Figure 3 ). This result suggests that soaking temperature and time were not sufficient to destroy $100 \%$ urease activity; further heat treatment was necessary to inactivate urease activity. Combination of blanching $\left(80^{\circ} \mathrm{C}\right.$ for $\left.10 \mathrm{~min}\right)$ and soaking at 55 and $60^{\circ} \mathrm{C}$ for 4 and $6 \mathrm{~h}$ did not show any significant $(\mathrm{p}>0.05)$ different in urease activity. Cold grinding in combination with soaking and blanching did not reduce $100 \%$ urease activity. However, Combination of hot grinding $\left(100^{\circ} \mathrm{C}\right)$, blanching $\left(80^{\circ} \mathrm{C}\right.$ for $\left.10 \mathrm{~min}\right)$ and soaking at different time and temperature could significantly reduce $100 \%$ urease activity. Heat treatment was adequate to reduce urease activity that might be a good indicator of trypsin inhibition.

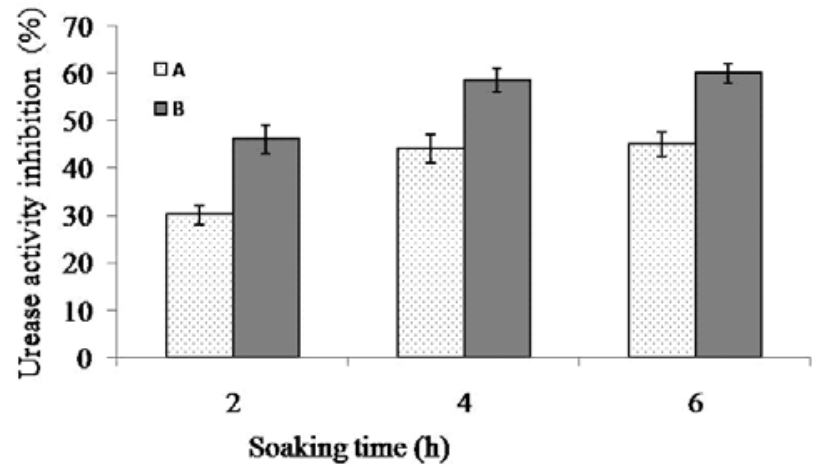

Fig. 3. Effect of soaking temperature and time on urease activity in the soy milk. $\mathrm{A}=$ Soybean soaking at $55^{\circ} \mathrm{C}$ temperature. $\mathrm{B}=$ Soybean soaking at $60^{\circ} \mathrm{C}$ temperature. Bars represent standard deviation.

Effect of combination of soaking, blanching and hot grinding on trypsin inhibitor content of soy milk

Extraction under combination of soaking, blanching and hot grinding $\left(100^{\circ} \mathrm{C}\right)$ significantly reduced more trypsin inhibitor in soy milk than extraction under combination of soaking, blanching and cold grinding (Figure 4). The heat treatment $\left(100^{\circ} \mathrm{C}\right)$ used for hot grinding extraction was not sufficient for complete destruction or inactivation of trypsin inhibitor. The result suggests that high heat treatment or steam grinding rather than hot water grinding are more effective for soy milk extraction. Heat-treatment in an oven at $150^{\circ} \mathrm{C}$ for 30 min for raw soybean before soy milk extraction or UHT for extracted soy milk will completely destroy trypsin inhibitor. Similarly, inactivation of inhibitors to desirable levels could be achieved after autoclaving soybeans at $120^{\circ} \mathrm{C}$ for 18 minutes and $121^{\circ} \mathrm{C}$ for 10 minutes, respectively (Machado et al., 2008; Mendes et al., 2007). However, wet heat treatment at high temperature could cause protein denaturation with concomitant loss of its functionality and generates additional volatile organic compounds that are responsible for cooked or toasted off-flavors (Ha et al., 1992). It is also known that the denaturation of protein by heating increases hydrophobicity (Shung-Tang et al., 1997). However, steam injected hot grinding could be useful for extraction of soy milk that would reduce nutrient loss of soy milk as well as inhibit the maximum amount of trypsin inhibitor. 


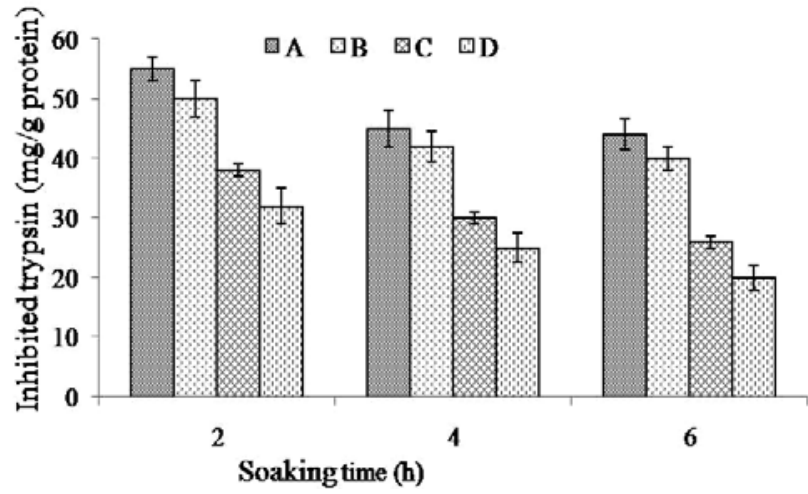

Fig. 4. Combined effect of soaking temperature-time, blanching $\left(80^{\circ} \mathrm{C}\right.$ for $\left.10 \mathrm{~min}\right)$ and grinding conditions on the trypsin activity in soy milk. $\mathrm{A}=$ Combination of soaking $\left(55^{\circ} \mathrm{C}\right)$, blanching $\left(80^{\circ} \mathrm{C}\right.$ for $\left.10 \mathrm{~min}\right)$ and cold grinding. $\mathrm{B}=$ Combination of soaking $\left(60^{\circ} \mathrm{C}\right)$, blanching $\left(80^{\circ} \mathrm{C}\right.$ for 10 min) and cold grinding. $\mathrm{C}=$ Combination of soaking $\left(55^{\circ} \mathrm{C}\right)$, blanching $\left(80^{\circ} \mathrm{C}\right.$ for $\left.10 \mathrm{~min}\right)$ and hot grinding $\left(100^{\circ} \mathrm{C}\right) . \mathrm{D}=$ Combination of soaking $\left(60^{\circ} \mathrm{C}\right)$, blanching $\left(80^{\circ} \mathrm{C}\right.$ for $\left.10 \mathrm{~min}\right)$ and hot grinding $\left(100^{\circ} \mathrm{C}\right)$. Bars represent standard deviation.

Effect of combination of soaking, blanching and hot grinding on protein solubility of soy milk

The protein solubility of soy milk was higher than that of raw soybeans ( $75 \%$ solubility). Only soaking time and temperature increased the minimum amount of protein solubility (maximum $10 \%$ increase at $60^{\circ} \mathrm{C} 6 \mathrm{~h}$ soaking) suggesting that the heat-treatment is very much necessary to increase the solubility. However, it is suggested that increasing the soaking temperature increased the protein solubility, but soaking time did not affect so much on protein solubility. Solubility of soy milk increased after blanching with $80^{\circ} \mathrm{C}$ for $10 \mathrm{~min}$. However, there is a significant difference between cold grinding-extracted soy milk vs hot grinding-extracted soy milk (Figure 5). Combination of soaking (55 and $60^{\circ} \mathrm{C}$ for 2, 4 and $\left.6 \mathrm{~h}\right)$, blanching $\left(80^{\circ} \mathrm{C}\right.$ for $\left.10 \mathrm{~min}\right)$ and hot grinding $\left(100^{\circ} \mathrm{C}\right)$ showed significantly higher amount of protein solubility than the other extraction procedure. This might be due to denaturation of soy protein during hot grinding though amino acid content did not change at this temperature (Kwok et al., 1998).

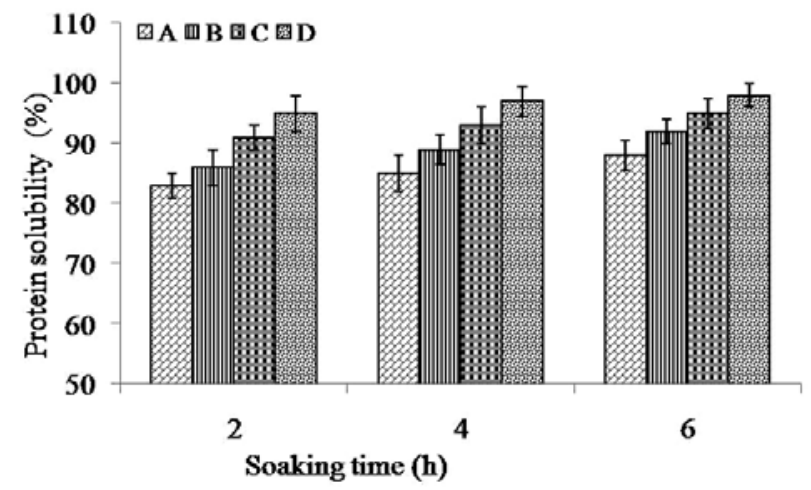

Fig. 5. Combined effect of soaking temperature-time, blanching $\left(80^{\circ} \mathrm{C}\right.$ for $\left.10 \mathrm{~min}\right)$ and grinding conditions on the protein solubility of soy milk. A= Combination of soaking $\left(55^{\circ} \mathrm{C}\right)$, blanching $\left(80^{\circ} \mathrm{C}\right.$ for $\left.10 \mathrm{~min}\right)$ and cold grinding. $\mathrm{B}=$ Combination of soaking $\left(60^{\circ} \mathrm{C}\right)$, blanching $\left(80^{\circ} \mathrm{C}\right.$ for 10 min) and cold grinding. $\mathrm{C}=$ Combination of soaking $\left(55^{\circ} \mathrm{C}\right)$, blanching $\left(80^{\circ} \mathrm{C}\right.$ for $\left.10 \mathrm{~min}\right)$ and hot grinding $\left(100^{\circ} \mathrm{C}\right) . \mathrm{D}=$ Combination of soaking $\left(60^{\circ} \mathrm{C}\right)$, blanching $\left(80^{\circ} \mathrm{C}\right.$ for $\left.10 \mathrm{~min}\right)$ and hot grinding $\left(100^{\circ} \mathrm{C}\right)$. Bars represent standard deviation.
Effect of combination of soaking, blanching and hot grinding on the nutrient content of soy milk

Soaking of soybeans in chemical solutions had a significant effect on the chemical composition and reduction in beany flavor in soy products (Khaleq et al., 1970). Soy milk prepared from soybeans soaked in sodium-bi-carbonate contained higher protein than soy milk prepared from beans soaked in water or sodium hydroxide (data not shown). Soybeans soaked in carbonate were easier to process than soaked in the other two solutions. However, sodium carbonate and sodium hydroxide had a significant effect on the reduction in beany flavor in soy milk (Giri and Mangaraj, 2012).

Soaking temperature and time with cold or hot grinding significantly affect the nutrient content of soy milk. Combination of soaking, blanching and hot water grinding significantly reduced carbohydrate content and increased the lipid with increasing extraction temperature from 55 to $60^{\circ} \mathrm{C}$ (Table 1). Maximum solids were extracted at 55 to $60^{\circ} \mathrm{C}$. Protein recovery started to decrease slightly at more than $70^{\circ} \mathrm{C}$. With higher extraction temperatures above $70^{\circ} \mathrm{C}$, there was an indication that the insoluble carbohydrate fraction, with hydroscopic and swelling properties, might significantly contribute to inhibition of filtration and cause losses in the solid yield of soy milk. However, the effect of shortduration soaking was predominantly leaching of watersoluble carbohydrate accounted for as much as $60 \%$ of the solids contained in the soaked water. About $6 \%$ of the soaked water solids was lipid and the remainder was crude protein. About $50 \%$ of soaked water crude protein was non-protein nitrogen. Increasing the soaking temperature from 55 to $60^{\circ} \mathrm{C}$ significantly increases the extracted solid content. Increasing soaking time from 2 to $4 \mathrm{~h}$, total solid content (protein and lipid) significantly increased; however, 4 to $6 \mathrm{~h}$ soaking time did not show any significant difference in terms of solid content.

Table 1. Refractive index, total solids, protein, fat and yield of soy milk per $250 \mathrm{~g}$ soybean under combination of soaking $(4 \quad h)$, blanching $\left(8^{\circ} \mathrm{C}\right.$ for $\left.10 \mathrm{~min}\right)$ and grinding conditions

\begin{tabular}{lcccl}
\hline Parameter & \multicolumn{2}{c}{$\begin{array}{c}\text { Hot water grinding } \\
\left(100^{\circ} \mathrm{C}\right)\end{array}$} & \multicolumn{2}{c}{$\begin{array}{c}\text { Cold water } \\
\text { grinding }\end{array}$} \\
\cline { 2 - 5 } & \multicolumn{3}{c}{ Soaking temperature for 4 h } \\
\cline { 2 - 5 } & $55^{\circ} \mathrm{C}$ & $60^{\circ} \mathrm{C}$ & $55^{\circ} \mathrm{C}$ & $60^{\circ} \mathrm{C}$ \\
\hline Refractive & $1.345^{\mathrm{a}} \pm$ & $1.339^{\mathrm{a}} \pm$ & $1.334^{\mathrm{a}} \pm$ & $1.333^{\mathrm{a}} \pm$ \\
index & 0.005 & 0.003 & 0.005 & 0.004 \\
Total solids \% & $7.65^{\mathrm{b}} \pm 0.03$ & $8.36^{\mathrm{a}} \pm 0.03$ & $6.37^{\mathrm{c}} \pm 0.05$ & $6.55^{\mathrm{c}} \pm 0.03$ \\
Protein \% & $4.46^{\mathrm{b}} \pm 0.07$ & $5.67^{\mathrm{a}} \pm 0.07$ & $4.02^{\mathrm{c}} \pm 0.05$ & $4.13^{\mathrm{c}} \pm 0.06$ \\
Fat \% & $2.15^{\mathrm{a}} \pm 0.06$ & $2.24^{\mathrm{a}} \pm 0.06$ & $1.80^{\mathrm{b}} \pm 0.00$ & $1.93^{\mathrm{b}} \pm 0.06$ \\
Yield (ml) per & $850^{\mathrm{c}} \pm 5.0$ & $880^{\mathrm{b}} \pm 5.0$ & $915^{\mathrm{b}} \pm 4.5$ & $950^{\mathrm{a}} \pm 4.0$ \\
250 g soybean & & & & \\
\hline
\end{tabular}

Mean \pm standard deviation values in the same column with different superscripts are significantly different ( $p>0.05$ ). 


\section{Conclusions}

Soy milk is a good source of protein, fat, and mineral contents. Soaking time and temperature along with hot or cold grinding reduced the anti-nutrient factors in soy milk. Soaking conditions did not considerably affect nutrient contents of soy milk; however, soaking temperature affected the nutrient content of soy milk. Hot grinding $\left(100^{\circ} \mathrm{C}\right)$ was found sufficient to reduce $100 \%$ of urease activity, more than $85 \%$ phytate and trypsin inhibitor, and increase protein solubility. It is concluded that soaking at $60^{\circ} \mathrm{C}$ for $6 \mathrm{~h}$ in combination with hot grinding $\left(100^{\circ} \mathrm{C}\right)$ with blanching at $80^{\circ} \mathrm{C}$ for 10 min is the best practice for producing high quality soy milk and other soy products.

\section{Acknowledgements}

The authors gratefully acknowledge Bangladesh Agricultural University Research systems (BAURES) for providing the Research Grant.

\section{References}

Akiyama, T., Ishida, J., Nakagawa, S., Ogawara, H., Watanabe, S., Itoh, N., Shibuya M. and Fukami, Y., 1987. Genistein, a specific inhibitor of tyrosine-specific protein kinases. J. Biol. Chem. 262(12): 5592-5595.

Adlercreutz, C.H.T., Goldin, B.R., Gorbach, S.L., Höckerstedt, K.A.V., Watanabe, S., Hämäläinen, E.K., Markkanen, M.H., Mäkelä, T.H,W., Adahälä, K.T. Hase, T.A. and Fotsis. T., 1995. Soybean phytoestrogen intake and cancer risk. J. Nutr. 125: S757-S770.

AOAC. 1999. Official Methods of Analysis of AOAC International, 16 th Edn., 5 th rev. Method 930.15. Association of Official Chemists, Gaithersburg, MD.

Bahceci, K.S., Serpen, A., Gokmen, V. and Acar, J., 2005. Study of lipoxygenase and peroxidase as indicator enzymes in green beans: change of enzyme activity, ascorbic acid and chlorophylls during frozen storage. J. Food Engg. 66: 187192.

Bishnoi, S., Khetarpaul, N.and Yadav, R.K., 1994. Effect of domestic processing and cooking methods on phytic acid and polyphenol contents of pea cultivars (Pisumsativum). Plant Food Hum. Nutr. 45(4): 381-388.

Croston, C.B., Smith, A.K. and Cowan, J.C., 1955. Measurement of urease activity in soybean meal. J. Am. Oil Chem. Soc. 32: 279-282.

Deak, N.A. and Johnson, L.A., 2007. Fate of phytic acid in producing soy protein ingredients. J. Am. Oil Chem. 84(4): 369-376.

Dhurandhar, N.V. and Chang, K.C., 1990. Effect of cooking on firmness, trypsin inhibitors, lectins and cystine/cysteine content of navy and red kidney beans (Phaseolus vulgaris). J. Food Sci. 55(2): 470-474.

Dia, V.P., Gomez, T., Vernaza, G., Berhow, M., Chang, Y.K. and de Mejia, E.G., 2012. Bowman-Birk and Kunitz protease inhibitors among anti-nutrients and bio-actives modified by germination and hydrolysis in Brazilian soybean cultivar BRS 133. J. Agric. Food Chem.60: 7886-7894.

Erlanger, B.F., Kokowosky, N. and Cohen, W., 1961. The preparation and properties of two new chromogenic substrates of trypsin. Arc. Biochem. Biophy. 95(2): 271-278.

Esteves, E.A., Martino, H.S.D., Oliveira, F.C.E., Bressan, J. and Costa, N.M.B., 2010. Chemical composition of a soybean cultivar lacking lipoxygenases (LOX2 and LOX3). Food Chem. 122(1): 238-242.

Felix, M.A., Canniatti, B.S.G. and Machado, F.M.V.F., 2011. Análise sensorial dos grãos de soja (Glycine max (L.) Merril) to stados pordiferentestratamentos. Ciênciae Tecnologia de Alimentos. 31(1): 56-64.

Fernandes, A.C., Nishida, W., and Costa Proença, R.P.Da., 2010. Influence of soaking on the nutritional quality of common beans (Phaseolus vulgaris L.) cooked with or without the soaking water: A review. Int. J. Food Sci. Tech. 45(11): 2209-2218.
Garcia, M.C., Torre, M., Marina, M.L. and Laborda, F., 1997.Composition and characterization of soyabean and related products. Critic. Rev. Food Sci. Nutr. 37: 361-391.

Giri, S.K. and Mangaraj, S., 2012. Processing influences on composition and quality attributes of soymilk and its powder. Food Engg. Rev. 4: 149-164.

Gokmen, V. Bahceci, S. and Acar, J., 2002. Characterization of crude lipoxygenase extract from green pea using modified spectrophotometric method. European Food Res. Tech. 215: 42-45.

Ha, E.Y.W., Morr, C.V. and Seo, A., 1992. Isoflavone aglycone and volatile organic compounds in soybeans: Effects of soaking treatments. J. Food Sci. 57: 414-426.

Hassler, C.M. 1998. Functional foods: their role in disease prevention and health promotion. Food Technol. 52(11): 63-70.

Khaleque, A., Bannatyne, W.R. and Wallace, G.M., 1970. Studies on the processing and properties of soymilk I.-Effect of preprocessing conditions on the flavor and compositions of soymilks. J. Sci. Food Agric. 21(11): 579-583.

Kwok, K.C., Shiu, Y.W., Yeung, C.H. and Niranjan, K., 1998. Effect of thermal processing on available lysine, thiamine and riboflavin content in soy milk. J. Sci. Food Agric. 77(4): 473-478.

Liu, K. 1997. Soybeans: Chemistry, Technology and Utilization. New York: Chapman and Hall, pp. 137-217.

Liu, K. and Markakis, P., 1987. Effect of maturity and processing on the trypsin inhibitor and oligosaccharides of soybeans. J. Food Sci. 52(1): 222-223.

Lowry, L.R., Rosebrough, N.J., Farr, A.L. and Randall, R.J., 1952. Protein measurement with the Folin phenol reagent. J. Biol. Chem. 193 (1): 265-275.

Machado, F.P.P., Queiróz, J.H., Oliveira, M.G.A., Piovesan N.D., Peluzio, M.C.G., Costa, N.M.B. and Moreira, M.A., 2008. Effects of heating on protein quality of soybean flour devoid of Kunitz inhibitor and lectin. Food Chem. 107(2): 649-655.

Mazumder, M.A.R. 2016. The roles of genistein as anti-browning agent in liquid and powdered emulsions. PhD thesis. Graduate School, Kasetsart University, Bangkok, Thailand

Mazumder, M.A.R. and Hongsprabhas, P., 2016a. Genistein as antioxidant and antibrowning agents in in vivo and in vitro: A review. Biomed. Pharmacoth. 82: 379-392.

Mazumder, M.A.R. and Hongsprabhas, P., 2016b. A review on nutrient quality of soy milk powder for malnourished population. Pakistan J. Nutr. 15(6): 600-606.

Mazumder, M.A.R. and Begum, A.A., 2016. Soy milk as source of nutrient for malnourished population of developing country: A review. Int. J. Adv. Sci. Tech. Res. 6(5): 192-203.

Mendes, F.Q., Oliveira, M.G., de Cardoso, L.R., Costa, N.M.B. and Sant `ana, R.de C.O., 2007. Digestibilidadeproteica e caracterizaçãobromatológica de linhagensdesoja com ausênciaoupresença do inibidor de tripsina Kunitz e das isozimaslipoxigenases. J. Biosci. 23: 14-21.

Monteiro, M.R.P., Costa, N.M.B., Oliveira, M.G. deA., Pires, C.V. and Moreira, M.A., 2004. Qualidadeproteica de linhagens de soja com ausência do Inibidor de TripsinaKunitz e das isoenzimas Lipoxigenases. Revista de Nutrição. 17(2): 195-205.

Riaz, M.N. 1999. Soybeans as functional foods. Cereal Food World. 44(2): 88-92.

Rounds, M.A. and Nielsen, S.S., 1993. Anion-exchange highperformance liquid chromatography with post-column detection for the analysis of phytic acid and other inositol phosphates. J. Chromatograp. 653: 148-152.

Savage, G.P. and Dubois, M., 2006. The effect of soaking and cooking on the oxalate content of taro leaves. Int. J. Food Sci. Nutr. 57(5-6): 376-381.

Schlemmer, U., Frølich, W., Prieto, R.M., and Grases, F., 2009. Phytate in foods and significance for humans: food sources, intake, processing, bioavailability, protective role and analysis. Mol. Nutr. Food Res. 53(2): S330-S375.

Sharma, A. 1992. Effect of processing and cooking on the antinutritional factors of faba bean (Viciafaba). Food Chem. 43(5): 383-385.

Shung-Tang, G., Ono, T. and Mikami, M., 1997. Incorporation of soy milk lipid into protein coagulum by addition of calcium chloride. J. Agric. Food Chem. 47: 901-909.

Wade, H.E. and Morgan, D.M., 1955. Fractionation of phosphates by paper ionophoresis and chromatography. Biochem. J. 60: 264-270. 